HStud 28 (2014)2, 235-254

DOI: 10.1556/HStud.28.2014.2.3

\title{
THE VISIT OF THE MOST POPULAR AMERICAN OF THE DAY: THEODORE ROOSEVELT IN HUNGARY
}

\author{
ZOLTÁN PETERECZ \\ Eszterházy Károly College, Hungary \\ E-mail: zpeterecz@yahoo.com
}

\begin{abstract}
It is a well-known fact that Theodore Roosevelt was and still is one of the most popular presidents of the United States. It is also somewhat known that he had a relatively brief, and relatively good relationship with Count Albert Apponyi, one of the most influential politicians of Hungary in the first three decades of the twentieth century. Perhaps a somewhat lesser known fact is that Roosevelt visited Hungary in 1910. As part of a European tour in the spring of that year, Theodore Roosevelt spent three days in Hungary. The courtesy visit was made into a huge and significant-looking event in Hungary behind which there were certain wishes, bitterness, and propaganda aims on the part of the Hungarian political leadership. Hungary hoped by the virtue of the ex-President's visit to prove the country's equal standing with Austria within the Dual Monarchy. Furthermore, the well-educated Roosevelt knew exactly what his hosts wanted to hear and, accordingly, although inadvertently, he kindled the flames of Hungarian independence, a concept with which he did not agree. The paper wishes to tell the story of Theodore Roosevelt's short stay in Hungary as well as the importance, and lack of consequences, of such a visit.
\end{abstract}

Keywords: Theodore Roosevelt, Hungary, Austro-Hungarian Monarchy, Count Albert Apponyi, Hungarian-American relations

After Theodore Roosevelt ${ }^{1}$ had left the presidency in 1909, he could not just stand or sit still. Driven by enormous amount of energy and childhood dreams, he set out on a months-long African hunting journey. After the conclusion of that trip, which resulted in various trophies and articles from the ex-president, Roosevelt turned his eyes on the European continent. He was coveted by basically every country in Europe and was hailed as the most popular and most influential person of the era. Though somewhat exaggerated as this statement may sound, there is some truth that Roosevelt was both popular and influential, which partly was thanks to the emergence of the United States as a burgeoning world power, which fact was made possible partially by Roosevelt himself.

It is little wonder then that Hungarians were very excited when it became known that the former president was going to pay a visit to the country. He was to 
be the first former president to have visited the country, ${ }^{2}$ and it served a much bigger purpose than a media event in the early twentieth century. It can be safely stated that Roosevelt's three-day visit in 1910, which was a stop on his European tour, put Hungary on the map of the political world after a long hiatus. Not since Kossuth's tour in the United States in 1851-52 had Hungary and Budapest been so often mentioned in the American press.

Theodore Roosevelt's visit was not important only in itself. Although Hungarians may have been accustomed to catching a glimpse of one or two kings and other high excellencies, such a prominent and popular person had never paid a visit earlier. The period, the pre-World War I years, meant the high point of Hungarian nationalism. The almost half century in the wake of The Compromise with Austria in 1867 had been spent by various Hungarian attempts to secure a larger independence within the Empire. This they wished to achieve by establishing the most evident appearance of a nation state. In this endeavor a prominent tool was the oppression of the various ethnic minorities, often their forced Hungarianization. Since the ratio of those minorities reached about $50 \%$ of the total population of Hungary, it is little surprise that the Hungarian political leadership from the late nineteenth century did everything in its power to arrest such a demographic tendency.

At the visit of Theodore Roosevelt this Hungarian effort was at its zenith. The leaders of the country welcomed every piece of possible positive propaganda in the belief that any such circumstance might mean a legitimate framework for Hungarian dominancy over other ethnicities in the Carpathian Basin. The minorities within Hungary craved for their own independent nation states at least with the same fervor, which in their eyes only seemed achievable by throwing off the Hungarian yoke. The Hungarians, therefore, thought that Roosevelt's visit came at the best possible moment, because the hosts interpreted the ex-presidential visit's stops as falling in the same category of importance, for example, Rome, Paris, London, and, perhaps most of all, Vienna. Although this was naturally a naïve and too optimistic understanding of the realities of the unofficial visit of a private person, it is still important to keep in mind that Hungary welcomed more than just an American who had held the highest office in his country earlier. The Hungarian leadership, and somewhat the population at large as well, anticipated a small-scale version of a modern-day Messiah in the person of Theodore Roosevelt. Through this prism must one observe the events concerning Roosevelt's visit to Europe and especially to Hungary, and investigate whether the three days here met with the high expectations, caused disappointment, or changed anything at all in the status quo, perhaps legitimized it to any degree.

It is important to note at the outset that at the momentous visit Hungary as a sovereign state did not exist and, on the other hand, the United States was still not an active participant as far as European political issues were concerned. Both of 
these factors played a role in the fact that the relations between the two countries were in a budding form at best. Since within the Austro-Hungarian Monarchy foreign affairs were a common ministry, one cannot speak of independent American-Hungarian relations. All forms of connections and information flow took place through the private sector. In this connection Count Albert Apponyi must be mentioned, who was probably the best known Hungarian statesman of the era, a respected political figure in the Western world. It is partially thanks to him that Roosevelt visited Hungary, while the other figure in this respect was Baron László Hengelmüller, ambassador of the Austro-Hungarian Monarchy to the United States. ${ }^{3}$ This again well underlines the fact that in diplomacy, or rather, in the lack of it, how important personal relations will become; how crucial it is whether next to the official and often rigid contacts that may exist between two states there are private channels. $^{4}$

Theodore Roosevelt, the $26^{\text {th }}$ president of the United States enjoyed a rare case of popularity, both at home and in foreign countries. In recent decades various rankings made by historians regularly put him in the first five among the presidents. ${ }^{5}$ Another sign of his popularity are his statue in front of the U.S. Capitol, and one of the four larger than life heads is his at Mount Rushmore. The secret for this popularity is manifold. Roosevelt is remembered as the first president who devoted his office to the progressive idea, started his trust busting policy, tried to improve low hygiene across the country, doubled the numbers of federally protected natural sites, or fought with some success governmental and municipality corruption. Furthermore, Roosevelt was also a learned historian and a prolific author mainly concerning the history of the United States in the nineteenth century. Aside from his books and articles, he often met with the people, and his being a great orator only increased his popularity. Another source of his popularity was his foreign policy. He firmly believed in a strong United States, which had a rightful place among the traditional European powers, but at the same time, he was an ardent nationalist and preached the superiority of the Anglo-Saxon peoples over other "backward" nations, especially in Latin American and Asia. Although these notions today are deemed politically unacceptable, a hundred years ago they were natural and coveted by large masses of Americans. Roosevelt believed in the triumph of war, and he personally took part in the Spanish-American War as a leader of the Rough Riders, a special military unit that he recruited. As president, Roosevelt was much more cautious in foreign policy, and can be described as an international realist. He always well chose where and to what extent to use American political influence or military power. His best-remembered political declaration is the Roosevelt Correlation to the Monroe Doctrine in 1904, in which he professed his belief that the United States ought to play the role of an international policeman in the Central American region, a concept that later was faithfully accepted and enlarged by his late successors. 
Today, the judgment on Roosevelt has a dual nature. Although basically everybody recognizes his undoubtedly successfully presidential years, however, since World War II more and more historians have put emphasis on his qualities and views that are seen as incorrect today. First, however, it is worth taking a look at the opinions of some of Roosevelt's contemporaries. Mark Twain thought that "Our people have adored this showy charlatan as perhaps no impostor of his brood has been adored since the Golden Calf." ${ }^{\circ}$ H. G. Wells opined that Roosevelt

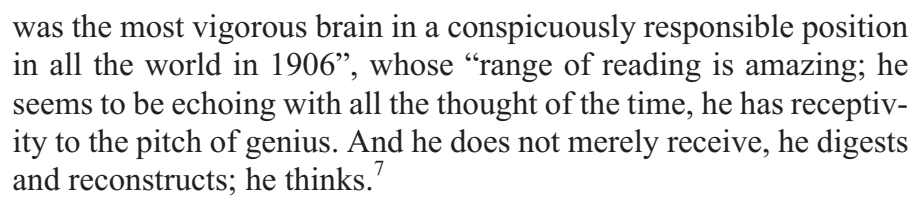

Henry Adams wrote of the president that "his restless and combative energy was more than abnormal" he "showed the singular primitive quality that belongs to ultimate matter - the quality that mediaeval theology assigned to God - he was pure act". 8

As a contrast, it serves well to observe some historians' view regarding Roosevelt. One of them summarized Roosevelt's character and political significance in the following manner:

A weird but decipherable combination of democrat, jingo, mission-
ary and Anglo-Saxon, he had nothing but contempt for the argument
that America should teach the world democracy by example alone. ${ }^{9}$

Perhaps Roosevelt's most eminent scholar, Edmund Morris, who devoted three bulky volumes to the whole life and career of Theodore Roosevelt, had this to say about the larger than life "Teddy":

He takes an almost mechanistic delight in the smooth workings of political power...With his clicking efficiency and inhuman energy, the President seems not unlike a piece of engineering himself. ${ }^{10}$

According to this biographer, Roosevelt's speeches were a typical amalgam of "aggression, vehemence, frankness, and authority, expressed in sentences a child could understand", while his attitude toward international affairs can be characterized as a "lifelong obsession with balance". "In 1906, in the First Moroccan crisis, for example, Roosevelt boldly asserted that as long as the balance of power was upheld by Britain in Europe, it was

well and good; should she however for some reason or other fail in doing so, the United States would be obliged to step in at least temporarily, in order to restore the balance of power in Europe, never mind 
against which country or group of countries our efforts may have to be directed". ${ }^{12}$

After seven and a half years of presidency, Roosevelt decided against another term, although constitutionally he could have run, because he deemed the presidential tradition set up by George Washington binding on himself. Instead, he picked William Howard Taft as his successor, while he, now again as a "simple citizen", full of energy and crave for adventure, set out to realize some of his dreams. That is why he ventured on an almost year-long safari hunting trip in Africa in 1909, which served various aims: entertainment, science, and politics. The latter label got much stronger when it became certain that after the conclusion of his trip in Africa, Roosevelt was going on a shorter, but obviously much more significant trip all across Europe. His spring journey across the continent was a real media event: countless American and European newspapermen wrote basically about every move and utterances of the former president. The most prominent place was England, where Roosevelt, aside from his important university speeches, was to attend the funeral of Edward VII, who had passed away during the early phase of the tour. Norway was another important scene, where Roosevelt was awarded the Nobel Peace Prize for his activities at bringing the Russo-Japanese peace under conclusion in 1905. Aside from these venues, Roosevelt met with Wilhelm II in Germany, the Italian king, Francis Joseph Austro-Hungarian emperor, and various other European prime ministers and dignitaries. Wherever he went, he was greeted with such reverence pomp as if he were a real king, partly because everybody was convinced that Roosevelt would be again the president of the United States. A small episode of this two-month European trip was Hungary and Budapest. ${ }^{13}$

In Hungary people and leaders alike looked forward to the approaching visit with excitement and high expectations. Quite a few kings and emperors had been guests in Hungary, but these were not always carefree and festive occasions. Despite the fact that since 1867 Hungary had been the number two nation within the Monarchy, and regardless the reality that it had extended its own dominance over different ethnic minorities inside the Carpathian Basin, Hungary could not be called an independent and sovereign state. It counted little that Hungary could boast of its own bicameral parliament when the three more important ministries with respect to independence, war, treasury, and foreign affairs were common, but mainly under the dominance of Vienna. ${ }^{14}$ As a result of this condition, the century-old dream of regaining total independence remained unfulfilled. Therefore, when Roosevelt had indicated that he would visit the country as a stop on his European tour, this bore significant propaganda value for Hungary and some loss of prestige for Vienna. 
Roosevelt, somewhat in accordance with his ebullient and controversial personality, made headlines at his very first stop on his European tour. What he put to his friend Henry Cabot Lodge as "an elegant row", was in fact a clash of religious free will and dogma, the prerogative of an American in the old world. ${ }^{15}$ At the visit to Rome the former president had been scheduled for an audience at the Pope after which he wanted to visit a Methodist church as well where he would have made a speech. Roosevelt, who himself belonged to the Dutch Reformed Church and was brought up in the aura of religious freedom in a country of multicolored faiths, thought that his plan was only natural. His idea, however, provoked vehement resentment on the part of the Vatican, which at every junction wished to consolidate its preeminence over other dominations. Roosevelt decided that he would at any rate explain to the American public why he insisted on either both visits or on neither, and pointed out that he was the friend of both Catholics and Protestants. He added that his being away from the United States made him once more realize that religious freedom was a fundamental right to any individual. ${ }^{16}$ Naturally, more was at stake here than meets the eye at first sight. For Roosevelt, the issue revolved around the question of the prestige of the United States, which question was always one of the most defining aspects for him. As he informed a close confidant, "No self-respecting American could allow his actions or his going and coming to be dictated to him by any Pope or King." ${ }^{17}$ In the end, Roosevelt visited neither place; the Vatican was not willing to receive him, while the Methodist had issued a declaration in the meantime that was considered depreciative concerning the Vatican. In his own judgment, Roosevelt managed to have the best possible outcome of the controversy. ${ }^{18}$

The Hungarian journals at the conclusion of the former president's Italian visit spread the major news: Theodore Roosevelt was coming soon. The first remarks proved already quite hyperbolic:

There is hardly a more popular name today in the world than that of Theodore Roosevelt. His assertive personality, commanding selfassuredness, and immaculate character did not only elevate him to the presidency of the United States, but ensured him a place in history as well. ${ }^{19}$

Since Roosevelt's arrival was not due for another two weeks, it can be safely stated that the Hungarian media, and in all probability the nation at large, saw the event and especially Roosevelt's person as of immense importance. In addition, the visit to Hungary came right in the wake of a few days in Vienna, and although the route was made in accordance with logistical prudence, the quick Vienna-Budapest axis offered a chance for all kinds of parallels between the two capitals and countries. Nevertheless, these two sites were only a warm-up to the really significant places on the agenda: Paris, Berlin, and in the end Cambridge and Oxford in 
England, which meant the final stop of Roosevelt's European tour. But the above quoted lines from a Hungarian daily contained a lot of truth in the sense that Theodore Roosevelt was truly one of the most well-known and celebrated persons both in Europe and overseas. Wherever he went he was greeted with the highest respect, which was partly attributed to his country that had grown immensely in power during his presidential years; but the deference was also due on account of the visitor's humanistic, educated, progressive side as a popular former president. It is also worthwhile to mention that many political leaders in Europe were confident in predicting that Roosevelt would soon be president again, thus the extra will to entertain him and establish the best possible personal relationship. ${ }^{20}$

In Vienna Roosevelt was met with even greater celebration than in Italy. Roosevelt remembered particularly two persons from his days in the Austrian capital: Francis Joseph, the Emperor, and Count Johann Wiltczek. The old sovereign made a positive impression on the American from a personal point of view. He recalled that he was "an interesting man", although not "a very able man, but he was a gentleman", and he also had good instincts. ${ }^{21}$ However, Roosevelt deemed Archduke Franz Ferdinand "a furious reactionary in every way, political and ecclesiastical both". 22 The conversation between the former president and the still active Austrian emperor was mainly about politics and hunting, in which subjects both men had plenty of experience. Francis Joseph made a sharp observation when he labeled himself as "the last representative of the old system", while to him Roosevelt "embodied the new movement, the movement of the present and the future". ${ }^{23}$ Next day's lunch at Count Wiltczek proved once again how advantageous the immense information that he had learned in his youth could be. Roosevelt's photographic memory stored the once seemingly unnecessary names and dates, and now, decades later, he was able to profit from them. When he laid eyes on a wall of a portrait of István Báthory, he could instantly place the man in the history of Central and Eastern Europe, to the utter amazement of his host.

During his stay at Vienna, Roosevelt visited a Hungarian hussar regiment stationed there. As a war veteran, who had always been fascinated by the glory attainable on the battlefield, he was naturally attracted to everything that was in connection with the military. His "rough riders" in the Spanish-American War in Cuba were in many ways similar to the Hungarian hussars, at least Roosevelt saw it that way. It was little surprise then that both the soldiers and their horses received his rapt attention, and he took pride in the fact that he was "received with the most genuine cordiality as a fellow soldier". ${ }^{24}$ And it is even more understandable that the Hungarian newspapers reported this piece of news as a major event. One of them emphasized that the things that mostly "captured his attention in Vienna were two Hungarian features: the Hungarian part of the hunting exposition and the Hungarian hussars". ${ }^{25}$ Another paper quoted Roosevelt as allegedly enthusiastically saying after the hussar meeting: "It was grand! I would be really 
happy to lead such a regiment. ${ }^{, 26}$ Roosevelt's close attraction to horses was interpreted in Hungary as a twin feature of the basic Hungarian trait concerning horses. And this set the tone for the media voices for the next few days: they tried to find some positive point that might move the swing in favor of Hungary as opposed to the Austrians and Germans.

Roosevelt, with his indispensable pince-nez, arrived in Hungary on April 17. In Pozsony he and his son, Kermit, were greeted by Count Albert Apponyi. The two men had known each other for a number of years. Apponyi was usually the leader of the Hungarian delegation to the Inter-Parliamentary Union. ${ }^{27}$ The $12^{\text {th }}$ Conference of the Inter-Parliamentary Union, which took place in the United States, on which occasion Apponyi paid a visit to Roosevelt at the latter's house in Oyster Bay. ${ }^{28}$ The relationship that started there and lasted about ten years can be said to have been good. As one of the scholars of this era put it, it was "one of the most important links in the American-Hungarian relations before World War I", which proved to be "one of the most shining and interesting chapters of American-Hungarian relations". ${ }^{29}$ Despite these claims, Roosevelt had a truly complex opinion about Apponyi.

One year after his visit to Hungary, Roosevelt wrote about Apponyi in a confidential private letter. By the nature of the writing, we can be assured that these are the most honest words that Roosevelt ever put on paper about the Hungarian statesman. As an opening, he clearly stated that Apponyi was "a really fine fellow", who "represented a type of Liberal much more common in Continental Europe prior to 1848 than at present; but in some ways, purely Hungarian". Moreover, the Hungarian Count impressed the former president as "not only an advanced Liberal in matters political but also in matters ecclesiastical". Roosevelt was especially impressed by the fact that despite his devout Catholicism Apponyi made serious friendships with Protestants, and thought that Apponyi "was like an American Liberal of the best type". At the same time, however, Roosevelt emphasized Apponyi's doctrinaire composition:

\footnotetext{
He was in theory an almost irrational advocate of immediate international peace... and yet he represented the violent and extreme Hungarian party which was practically working for a separation from Austria that would probably bring war.
}

As he put it, Apponyi "was shocked and puzzled by finding that a large number of Hungarian Slavs regarded his attitude, and the attitude of the Magyars, toward them as itself an attitude of pure oppression". In all likelihood Roosevelt understood well why their relation was so friendly: 
One reason why he and the other Hungarian politicians whom I met got on well with me was probably the fact that I knew a good deal of Hungarian history and Hungarian constitutional claims. ${ }^{30}$

The overture in Pozsony set the tone for Roosevelt's whole stay in Hungary. The enthusiastic crowd that he experienced here was only a taste of what was in store. As one person of his entourage recalled,

the Hungarians, eager for their independence, shouted themselves hoarse at sight of the representative of American independence. Wherever he went the masses in the cities crowded round him and the people in the country flocked to cheer him as he passed. ${ }^{31}$

The high expectations sometimes resulted in undue exaggerations. One Hungarian newspaperman thought he had heard Roosevelt whisper to the correspondent of the New York Herald, "At last I am among friends!" 32 The former president's first speech in front of the Hungarian audience did not disappoint.

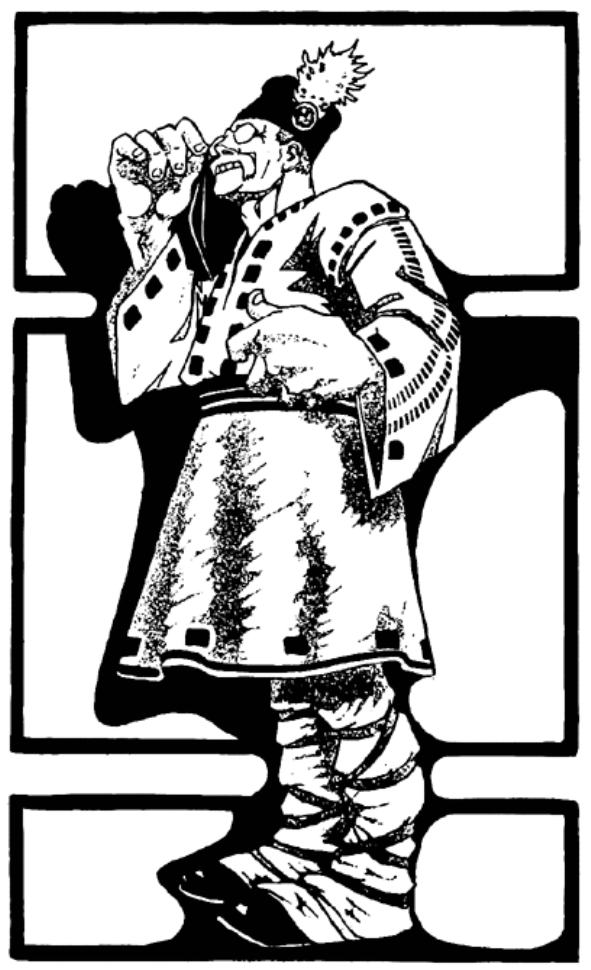

Teddy in Budapest

Source: Gruelle in the Cleveland Press. 
He praised the Hungarian nation on account of its history. He also found a parallel between the two nations because of the love of horses. He easily stimulated the people with such lines as "There is certain intrepidity, freedom, and enthusiasm in the Hungarian character that I always found admirable."33 Every such sentence, which was translated to the audience one by one, was greeted by tumultuous applause, and this was the impression with which he started to Apponyi's estate at Éberhard for lunch and a little rest. Along the way they passed many small villages and it struck Roosevelt as strange that in every village people spoke another language: Hungarian, German, or Slovakian. ${ }^{34}$ This experience provided him with proof for the colorful ethnicity of Hungary and further convinced him that Hungary's leaving the Monarchy would lead to war. The conversation between Roosevelt and Apponyi is a mystery in the sense that there is no record about it. The only thing that seems certain is that Apponyi signaled to Roosevelt that he would welcome the American's help in having the Outlook (Roosevelt's unofficial newspaper outlet) use Apponyi as its Hungarian correspondent. ${ }^{35}$ After a short rest Roosevelt was on the road again and arrived in Budapest at late evening, the obviously most important scene of his Hungarian trip.

According to eyewitnesses, despite the rain and the late time of the arrival of Roosevelt, people lined up from the railway station all the way to the central square. After many handshakes Mayor István Bárczy welcomed the prominent guest. In his acceptance speech Roosevelt chose a tone similar to the one at Pozsony:

\footnotetext{
I am not only a friend but a true admirer of the Hungarian nation. In your welcome you said I was the friend of Hungarians; well, by this you also said the friend of freedom; since, as far as I know, the Hungarian nation has always belonged to the most freedom-loving peoples. I can only repeat that I am surprised at the distinguished and honorable welcome and I am honest when I say that I cannot find words to express my thanks and gratitude. Hurray for Hungary"36
}

It is easy to imagine that the people present were delighted and "indescribable enthusiasm came over the crowd". ${ }^{37}$ After this celebration the illustrious guest went to his lodging at the Hotel Hungaria, where he held a quick press conference for the English-speaking reporters. Such media outlets had their correspondent follow Roosevelt's trip in Hungary as the Associated Press, the New York World, the New York Sun, the Chicago Tribune, and the London Daily Mail.

The program of the second day was just as busy, but Roosevelt was famous for both his fervor and the accompanying energy: a program that would have been exhausting for someone else for him was average. He visited the Royal Palace, the office of the Prime Minister, then again the Palace after which came, as it turned 
out, the high point of not only the day but that of the whole trip. This small episode cemented his reputation for a long time to come in Hungary, and in the interwar years his words uttered here were often recalled as proof of Hungary's proper place in the world.

Roosevelt paid a visit to the Parliament, where, thanks to the organization of Count Apponyi, he was the guest of honor at the meeting of the Hungarian members of the Inter-Parliamentary Conference. The impromptu speech that he performed here made the already very popular former president practically a superstar in the eyes of all Hungarians. Although only the newspapers printed what Roosevelt said, since there was no difference among these accounts there is no reason to doubt that the American did say the following words:

\begin{abstract}
I do not only respect and hold sympathy for Hungary but I am also an admirer of her, because I know that throughout the history of Hungary there are several lessons that are worth while for us and every other nation to learn. From these we can learn the lesson of bravery and the lesson of iron resolve and perseverance. Gentlemen! The whole civilized world is indebted to Hungary for her work. When America was still in Europe's womb, Hungary was protecting the safety of the civilized world by preventing barbarism from spreading. The merit belongs to your ancestors since it was they who repelled those attacks which were coming from the barbaric world and were aiming at Western culture, since it was their bodies that stopped the advance of barbarism. Washington's nation in the large cities of the Western Hemisphere still looks with admiration at your great, brave, and noble kings, at the glorious soldiers fighting in Transylvania and on both sides of the Danube, and at those many triumphant victories that they fought. There is no more illustrious history than that of the Hungarian nation. I know this history and I would not deem myself an educated man if I did not know it. ${ }^{38}$
\end{abstract}

It is natural that after these words, which were often interrupted by applause, "there was an ovation lasting for several minutes". 39

It is clear that when the speech appeared in the newspaper columns the echo was a huge collective joy on part of the Hungarian readers. It is easy to understand that a nation that had been vying and craving for independence again for centuries now thought that at last it had found an apparent benefactor, or at least a prominent politician from overseas, someone from the New World who knew and understood the stormy but glorious past of Hungarian history. One of the Hungarian newspapers put it right when it summarized why Roosevelt proved so sympathetic in Hungarian eyes: 
This one man's testimony compensates us for the twisted and poisonous opinion of half the world, because there is more moral weight and human truth in it than in the superficiality of misled millions" 40

Although Roosevelt's words do sound as a statement for propaganda consumption, consciously prepared for a target audience, there is no reason to assume that he did not speak what he really thought and meant. From his early studies he was really knowledgeable about the history of Hungary, which knowledge now served him very well. Furthermore, these were not scripted words; the former president improvised, that is, he had not prepared a speech but reacted on the spur of the moment. Obviously his wide range of knowledge, oratorical skills, and many years in the limelight made it for him easier to formulate those sentences. Still, he was honest in uttering them and it is little wonder that they created enormously positive feedback.

There were various reasons why it was in the interest of the host country to have a positive Hungarian-picture by Roosevelt. One of them, the most apparent, was any support for the cause of Hungarian independence. As it was pointed out earlier, Roosevelt was of the opinion that the dual Monarchy was the practical path from a geopolitical point of view. When three years after his Hungarian trip the former president wrote a short preface to László Hengelmüller's, the former and first minister from the Austro-Hungarian Monarchy, book on Hungary, Roosevelt did not miss to express this thought again. Although he once more expounded the maxim that "establishment of Hungary as a bulwark against further Asiatic invasion of Europe", he added,

All wise and far-seeing men earnestly hope for the continuation of the Dual Empire, the Empire Kingdom in which the same man is Emperor of Austria and Apostolic King of Hungary. ${ }^{41}$

Thus, Hungarians had to be content with the laudation of their past, but this was no small solace: the nation that was starving for proper foreign recognition sucked up Roosevelt's words. It is also of some importance to note here that Roosevelt, too, found the positive role for Hungarians in their fights against barbarians from the east; this was the link that connected them with the West. During the long struggle against the Turks Hungary slowly drifted to the brink of total collapse as a state while Western Europe escaped the worst. But one ought not to forget either that until that historic calamity commenced, Hungarians were not either very welcomed or esteemed in the western part of Europe. As soon as though it sacrificed itself for a "higher" standard of civilization, it was promptly exalted, it achieved respect, and became the "bastion of Christianity". It is largely thanks to Pope Pius II in the middle of the fifteenth century that this notion widely spread and Hungary became the stereotype of a defense line both in Western European and Hungarian 
eyes. ${ }^{42}$ As this respect and esteem started to fade, Hungarians were very grateful when a leading citizen of the United States repeated those praises.

The other aspect that bears some significance is the multitude of Hungarians who had emigrated to the United States. From the 1880s the number of immigrants from Eastern Europe grew steadily and Hungary was no exception. In Hungary it was a widespread belief that the president in power had a defining say concerning the situation of the huge wave coming to the shores of the United States. It is obvious that in the beginning of the twentieth century few Hungarians knew and understood the constitutional rules and practice of the overseas country, and in light of this it is little surprise that such ideas could be read as "We need his [Theodore Roosevelt's] sympathy; we see some insurance in this with regard to the fate of our blood overseas. ${ }^{\prime 43}$ Since Roosevelt had good relations with the Republican division of the Hungarian colony in New York City, as with countless similar such groups, many people in Hungary came to the conclusion that he must be a friend of Hungary. This notion was only strengthened by the widely held belief that "Roosevelt, the quintessential Yankee, the prototypical American, possessed Hungarian characteristics in many ways". "These traits were courage, impulsiveness, good heart, and, of course, his horse-riding nature. All these well represent how naïve pre-World War I Hungarians were in their perception of the world at large, how much they were longing for recognition, and how utterly they disregarded hard realities.

The rest of the program was as busy as colorful. After brunch at the Palace as the guest of Archduke Joseph, Roosevelt paid a visit to Ferenc Kossuth, leader of the Kossuth Party. The former president immensely enjoyed the tour at the Agricultural Museum after which he visited sculptor György Zala. During his conversation with the artist, the topic turned to Hungarian literature. When Mór Jókai's name came up, Roosevelt said:

\section{Where is Mikszáth? I have read in English translation one of his nov- els, The Umbrella of St. Peter's. I very much would like to meet with Mikszáth. ${ }^{45}$}

Indeed, a casual meeting was arranged for the evening, an occasion what a scholar termed "an essential building block in the history of Hungarian-American ties". 46 Then came the Washington statue in the City Park, which was unveiled four years earlier, and Roosevelt was the first prominent American public figure to lay a wreath on it. Later he had late lunch with the local American colony at the American Consul General's residence. When he had returned to his lodging, first he met a delegation of priest students, than he found time for American, British, and Hungarian journalists alike. Since a large mass of people continually cheered his name, he stepped out on the balcony and one more time addressed the people. Cal 
O'Laughlin, one of the journalists that accompanied Roosevelt, recorded this event in the following, somewhat hyperbolic fashion:

With every expression there was a shout which rolled over the berg across the river and came back in a thundering echo. I have seen many demonstrations, but that one by the Danube has not been surpassed in my experience. ${ }^{47}$

The evening offered a sumptuous dinner at the Park Club, where everybody who counted was present. The program of the day ended at the National Casino, while the next morning Roosevelt travelled to Bábolna to see the famous local animal farm.

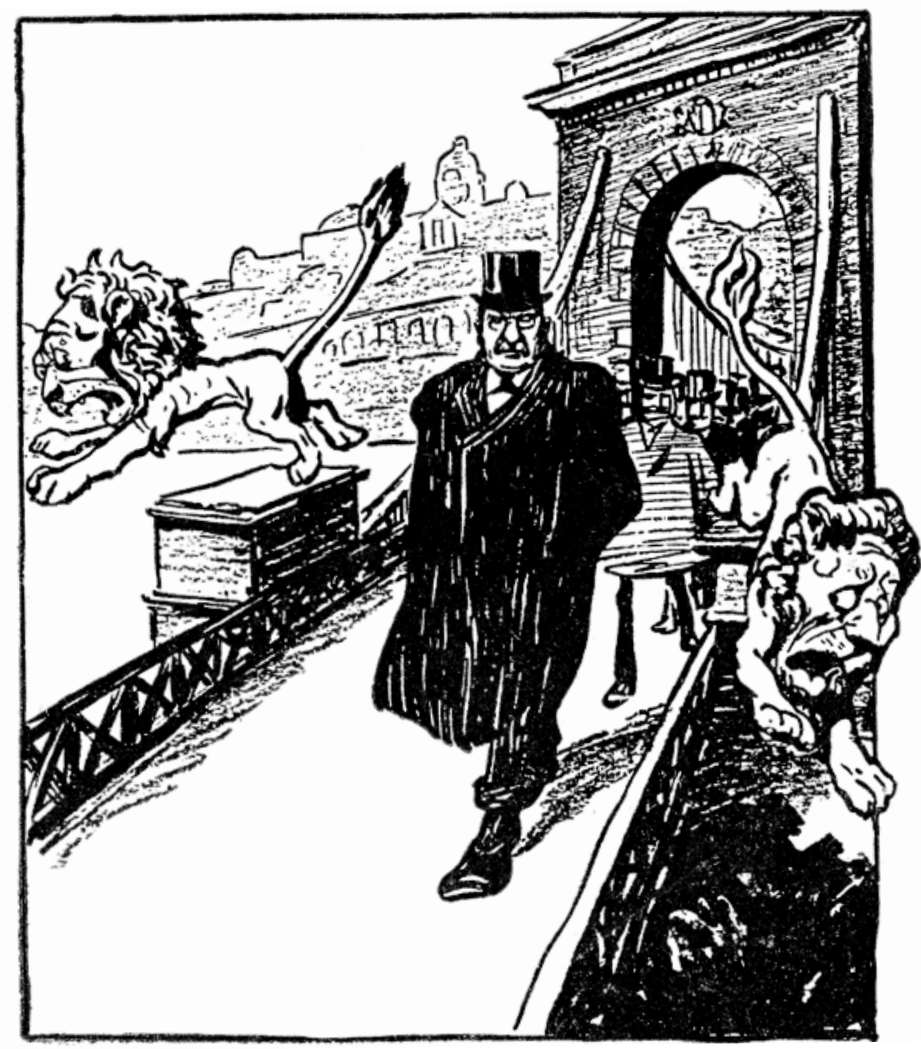

"Here's the Lion-Hunter"

- And the stone lions are fleeing for their lives!

Source: Kakas Márton (Budapest). 
When it was time to say goodbye, Roosevelt's farewell followed the well-established pattern of the last two days: he praised his hosts and with that he only managed to increase the already immense sympathy that was his share.

I will always think of you with the utmost gratitude, and as long as I live, I will cherish these memories, and everywhere I go I will be the spokesman of the Hungarian nation, because I know that the best way to praise it is describe their true nature. I will work on it that the Hungarian people should receive everywhere the respect and esteem that are their due. ${ }^{48}$

It is a well-known fact that Theodore Roosevelt had great oratorical gifts. His speeches were typically of great design and well formulated. This was no different during his stay in Hungary. Of course, that tells something about the lack of importance of Hungary that Roosevelt's speeches here were not pre-written and well-composed performances in sharp contrast to his speeches held in Berlin, Oslo, Paris, or those in England. While those were well thought out, carefully structured, and painstakingly edited orations, the Hungarian speeches were improvised, the given moment being their impetus. As he himself said to a journalist after his famous Parliament speech,

\begin{abstract}
to tell the truth, I did not prepare for it. As I was going to the meeting of the conference, I did not know what I was going to say, but Count Apponyi's speech, the moment, and the environment all gave me some inspiration and, as a consequence, they created sublime feelings and soaring thoughts in me. ${ }^{49}$
\end{abstract}

Obviously Roosevelt was very prepared, as a professional public figure and speaker ought to be, and Roosevelt was just that to the core. He knew very well what he was supposed to say in each country, what the given people may have wished to hear from him. Still, it is essential to note that not only were his speeches in Hungary that of an impromptu nature, but neither were those made in Rome or Vienna composed in advance. So, as a matter of importance, these countries or cities did not achieve the same rank as the great capitals of the West, either: Berlin, Paris, or London.

At any rate, irrespective of how elaborate they were, whether they were well-composed or really improvised in the heat of the moment, one thing is certain: they landed in the heart of the Hungarian audience and readership. This can be attributed both to Roosevelt's self-assured but easygoing and friendly style and his thorough knowledge of Hungarian history. His familiarity with the latter, such as the relationship between Hungarians and Austrians or Croats, came from his youth, but he did believe that "any ordinary scholar with a good second-hand 
knowledge of history is acquainted with all this as a matter of course; but among politicians the one-eyed is apt to be king - so far as concerns foreign history". This American politician understood that Hungarians appreciated so much the mentioning of their heroes of the past because he himself saw a parallel with the former American experience in this field.

Evidently they felt as regards the ignorance they encountered concerning their own national history when they went to Berlin, Paris, or London, much as an American felt forty or fifty years ago, when he found that Europe quite simply ignored the men and events that he had believed to be of capital importance.

As he further put it,

\begin{abstract}
it was the feeling of injured dignity natural to the man who does not like to have his cherished heroes and their deeds treated as provincial, and who is not as yet sufficiently self-confident to realize that such treatment reflects, not on him or them, but on those who really show themselves provincial by failing to appreciate the fundamental importance of what has happened outside their own kin.
\end{abstract}

The proof that Roosevelt indeed had a good mental insight into the Hungarian soul may be found in his following lines:

To a Hungarian the fact that the Golden Bull was analogous to the Great Charter, and was issued about the same time that the latter was signed, seemed of such interest that he could not understand an Englishman never having heard of the said Golden Bull; and in consequence he was much pleased to find that an ex-President from across the ocean had heard about it, and knew for instance that it solemnly reserved to the nobles the right of revolution if the king misbehaved himself. ${ }^{50}$

Therefore, Roosevelt not only proved himself a good historian who was able to cite certain facts at random notice, but he was a master psychologist at the same time.

If one studies the speeches that Roosevelt made in Western Europe, one can find nuances that make it clear that although the speeches in Hungary were spontaneous in fact, the main points of them were well within certain boundaries that had been laid down before. The three most significant stops on his European tour, Paris, Berlin, and Oxford, were written well in advance. For instance, in Paris, a few days after the warm words for the Hungarian audience, Roosevelt mentioned that "probably the best test of true love of liberty in any country [is] in the way in which minorities are treated in that country". ${ }^{51}$ He elegantly avoided any such 
topic while in Hungary. With another thought though, the one that he expressed at Oxford, the Hungarian political elite would have been in much agreement, and Roosevelt's following line would have been welcomed in Hungary:

In the long run there can be no justification for one race managing or controlling another unless the management and control are exercised in the interest and for the benefit of that other race. ${ }^{52}$

Roosevelt knew the Hungarian past and present much more than to arouse such charged emotions. Moreover, as for the time being, he believed with his whole heart in the Austro-Hungarian Monarchy being held together, therefore alone his geopolitical views would not have been a proper basis, on the one hand, to incite the minorities living in Hungary, who made up almost half of the total population, and to offend his Hungarian hosts on the other.

How should then Theodore Roosevelt's Hungarian trip be evaluated, especially with a view on American-Hungarian relations? It was by all means a significant event, because this was the first time that a former president had visited Hungary. Furthermore, this took place at the juncture when the United States had become a world power, even if its potential did not reach its limits and many in Hungary could not appreciate what this new and energetic country would be capable of in the future. It must be emphasized again that Hungary was not a sovereign, independent state, and that Roosevelt came to Hungary not in an official capacity but only for a friendly short stay, so his few days here did not bear significantly on diplomatic or political questions. That is a different question that in Hungary many people wanted to magnify the obvious importance of the former president's visit, thereby ensuring larger prestige to the Kingdom of Hungary. It can be stated that a country that remained part of the east but wanted to become somehow part of the west, a country that partly on account of the aforementioned fact had a certain amount of inferiority complex, a country that was full on insecurity - all these symptoms can be diagnosed in the overvaluation of Roosevelt's days in Hungary. It is undisputable that Budapest was Roosevelt's most eastern stop, in itself an achievement for Hungary, and it was on the same rank of importance as Italy, Austria, or Denmark. But it is also beyond doubt that Count Albert Apponyi and his relationship with the former president played a large role why Roosevelt picked Hungary as a place to visit; without such an influence there probably would have been no Hungarian stop on the European tour. In any event, by spending almost three days in Hungary, Roosevelt gave an enormous uplift to the Hungarian nation and politics alike, even if this could not be converted into hard political currency. Still, after 60 years of the Kossuth-tour in the United States, the American-Hungarian relations were started in many ways with Theodore Roosevelt, and his Hungarian visit in 1910 was an important stop of this evolution. 


\section{Notes}

1 Theodore Roosevelt (1858-1919) is still very popular both in the eye of the American public and among American historians. Some of the major works dealing with his life and presidency are George E. Mowry, The Era of Theodore Roosevelt and the Birth of Modern America, 1900-1912, (New York: Harper \& Row, 1962); William H. Harbaugh, Power and Responsibility: The Life and Times of Theodore Roosevelt (New York: Farrar, Straus and Cudahy, 1961); Edmund Morris, The Rise of Theodore Roosevelt (New York: Ballantine Books, 1979); David McCullough, Mornings on Horseback: The Story of an Extraordinary Family, a Vanished Way of Life, and the Unique Child Who Became Theodore Roosevelt (New York: Simon and Schuster, 1981); Lewis L. Gould, The Presidency of Theodore Roosevelt (Lawrence, KS: University Press of Kansas, 1991); Edmund Morris, Theodore Rex (New York: Random House, 2001); Edmund Morris, Colonel Roosevelt (New York, 2010), and Lewis L. Gould, Theodore Roosevelt (Oxford University Press, 2012).

2 The first president in office who paid an official visit to Hungary was George Bush in 1989.

3 Zsolt K. Virágos, Mikszáth and Roosevelt, in Hungarian-American Ties. Essays and Studies in Intercultural Links and Contacts, ed. by Zsolt K. Virágos (Debrecen: Debrecen University Press, 2013), 272.

4 In the English-language historiography, Roosevelt's visit is hardly mentioned. The three works that I know of are Imre Major Mark, American Hungarian Relations 1918-1944 (Astor, FL: Danubian Press, Inc., 1974); Tibor Glant, Through the Prism of the Habsburg Monarchy: Hungary in American Diplomacy and Public Opinion during the First World War. War and Society in East Central Europe, vol. XXXVI (Highland Lakes, NJ: Atlantic Research and Publications Inc., 1998; distributed by Columbia University Press); and Morris, Colonel Roosevelt.

5 As an average result of the last four such surveys, Roosevelt has the distinguished $4^{\text {th }}$ place. Nate Silver, "Contemplating Obama's Place in History, Statistically", The New York Times, January 23, 2013. http://fivethirtyeight.blogs.nytimes.com/2013/01/23/contemplatingobamas-place-in-history-statistically/ [Accessed April 12, 2013.]

6 Mark Twain to Walter Bliss, March 6, 1908, reprinted in The New York Times, May 31, 1912.

7 H. G. Wells, Experiment and Autobiography (New York: Macmillan, 1934), 649; and Wells, The Future in America: A Search after Realities (New York: Harper \& Brothers, 1906), 248.

8 Henry Adams, The Education of Henry Adams (New York: The Heritage Press, 1942), 389.

9 Clinton Rossiter, "The American Mission", The American Scholar, vol. 20, no. 1 (Winter 1950-51), 26.

10 Morris, The Rise of Theodore Roosevelt, xxi.

11 Ibid., 520; Morris, Theodore Rex, 383.

12 Quoted in Michael Lind, The American Way of Strategy (Oxford, New York: Oxford University Press, 2006), 93.

13 In more detail about Roosevelt's European trip, see Morris: Colonel Roosevelt, 40-79.

14 As Pál Pritz showed, however, in the domain of foreign policy, the Hungarian interests were better represented than typically thought earlier. Pál Pritz, "Két elvtárs - két mentalitás" [Two Comrades - Two Mentalities], In: Pritz, Pál, Magyar diplomácia a két világháború között [Hungarian Diplomacy between the Two World Wars] (Budapest, Magyar Történelmi Társulat, 1995), 9.

15 Henry F. Pringle, Theodore Roosevelt: A Biography (New York: Harcourt Brace, 1931), 513.

16 Theodore Roosevelt, "A Message to the American People", The Outlook, April 3, 1910.

17 William Roscoe Thayer, Theodore Roosevelt: An Intimate Biography (Boston: Houghton Mifflin, 1919), 323. 
18 Joseph Bishop Bucklin, Theodore Roosevelt and His Time Shown in His Own Letters, Vol. 2 (New York: Charles Scribner's Sons, 1920), 200. To the Vatican affair, also see Pringle, Theodore Roosevelt, 513-15.

19 Budapesti Hirlap, April 8, 1910, vol. 30, no. 81.

20 Theodore Roosevelt did indeed try one more time to reach the presidency, but in 1912 he lost to the Democrat Woodrow Wilson.

21 Bucklin, Theodore Roosevelt, 216.

22 Morris, Colonel Roosevelt, 43.

23 Bucklin, Theodore Roosevelt, 216.

24 Bucklin, Theodore Roosevelt, 218.

25 Budapesti Hirlap, April 19, 1910, vol. 30, no. 92.

26 Magyarország, April 17, 1910, vol. 17, no. 91.

27 About Apponyi's Inter-Parliamentary experiences see Albert Apponyi, The Memoirs of Count Apponyi, 1935, C2/3310 [Központi raktár] 229-231, 235

28 In more detail about this meeting, see Tibor Glant, Roosevelt, Apponyi és a Habsburg Monarchia [Roosevelt, Apponyi, and the Habsburg Monarchy], Századok, vol. 131, no. 6 (1997): 1388-89. On Apponyi's tour in the United States and his own account of the meeting with Roosevelt, see Apponyi, Memoirs, 130-44.

29 Glant, Roosevelt, 1399, 1400.

30 The quotations in the paragraph come from a letter from Roosevelt to George Otto Trevelyan Bart, October 1, 1911, quoted in Bucklin, Theodore Roosevelt, 220, 221, and 222. Roosevelt's whole account of his visit to Hungary is in Ibid., 220-6.

31 Thayer, Theodore Roosevelt, 324.

32 Budapesti Hírlap, April 19, 1910, vol. 30, no. 92.

33 Ibid.

34 Morris, Colonel Roosevelt, 44.

35 Glant, Roosevelt, 1392. This request provided Apponyi only with somewhat unfulfilled publication possibilities.

36 Budapesti Hírlap, April 19, 1910, vol. 30, no. 92.

37 Ibid.

38 Budapesti Hirlap, April 19, 1910, vol. 30, no. 92.

39 Ibid.

40 Budapesti Hirlap, April 19, 1910, vol. 30, no. 92. The created foreign "Hungarian picture" offers an interesting comparison with Hungary's political position today within the European Union, especially if one recalls Roosevelt's question to Count Apponyi at their meeting in Hungary: "Why are foreign countries angry with you, Hungarians?" Quoted in József Kerekesházy, Apponyi (Budapest: Singer \& Wolfner, 1943), 193. This should be the topic of another study.

41 Theodore Roosevelt's Preface to Ladislas Baron Hengelmüller, Hungary's Fight for National Existence, or The History of the Great Uprising Led by Francis Rakoczi II. 1703-1711 (London: Macmillan and Co., Ltd., 1913), xv-xvi.

42 József Marton, Magyarország képe és megítélése Enea Silvio Piccolomini életművében [The Picture and Judgment of Hungary in the Oeuvre of Enea Silvio Piccolomini], Irodalomtörténeti Közlemények, vol. 110, no. 5 (2006): 468-76.

43 Magyarország, April 19, 1910, vol. 17, no. 93.

44 Pesti Hírlap, April 19, 1910, vol. 32, no. 92.

45 Budapesti Hirlap, April 19, 1910, vol. 30, no. 92. A short meeting took place the following day at the Hotel Hungaria. 
46 Virágos, Mikszáth and Roosevelt, 271. Mikszáth died five weeks later in the wake of pneumonia he had contracted the year before.

47 Morris, Colonel Roosevelt, 45.

48 Budapesti Hirlap, April 20, 1910, vol. 30, no. 93.

49 Pesti Hirlap, April 19, 1910, vol. 32, no. 92.

50 The quotations of the paragraph are from Bucklin, Theodore Roosevelt, 222 and 223.

51 Theodore Roosevelt, The Man in the Arena, Speech at the Sorbonne, Paris, France, April 23, 1910, http://www.theodore-roosevelt.com/trsorbonnespeech.html [Accessed September 24, 2013.]

52 Theodore Roosevelt, Biological Analogies in History, delivered before the University of Oxford, June 7, 1910, (London: Henry Frowde, 1910), 41. 